\title{
Microsatellite polymorphism in DRB1 gene (MHC class II) and its relation to nematode faecal egg count in Polish Heath Sheep
}

\author{
K.M. Charon ${ }^{1}$, B. Moskwa' ${ }^{2}$ R. Rutkowski', J. Gruszczyńska' \\ and W. Świderek ${ }^{1}$ \\ 'Department of Genetics and Animal Breeding, Warsaw Agricultural University \\ Ciszewskiego 8, 02-786 Warsaw, Poland \\ 2 W. Stefański Institute of Parasitology, Polish Academy of Sciences \\ Twarda 51/55, 00-818 Warsaw, Poland
}

(Reccived 14 September 200I; accepted 31 January 2002)

\begin{abstract}
Parasitological examinations and the investigation of polymorphism in locus DRB 1 , belonging to MHC class I1, were conducted in a llock of Polish Heath Sheep in the years 1995-1998. The intensity of parasite infection of dams ranged from 0 to $24000 \mathrm{cggs}$, whereas for lambs it reached up to 27000 nematode eggs in 1 gram of faeces. In the years 1995-1997 nematode species dominant in the infection were $H$. contortus and $T$. colubriformis, while in 1998 the predominant was $T$. circumcincta.

DNA analysis of the examined sheep showed the presence of 20 alleles in locus DRB1, established on the basis of the length of a fragment of this gene amplified using PCR (cxon 2 and microsatellite in intron 2).

The analysis of variance conducted for the FEC trait in genotypic groups showed a statisticaily significant $(\mathrm{P} \leq 0.01)$ association between the genotype in locus DRB1 and number of nematode eggs in sliecp faeces. The presence of a given DRBI allele in the genotype of animats examined had significant effect on parasite resistance. Moreover, the significant association between the FEC value in allelic groups of paternal half-sibs and the segregation of paternal alleles was also significant $(\mathrm{P} \leq 0.05)$.
\end{abstract}

KEY WORDS: sheep, gastrointestinal nematode, MHC II, DRBI gene, resistance

\section{INTRODUCTION}

From the breeding point of view, parasite infections cause a serious problem, as they do not make it possible to fully utilise the production potential of farm animals. 
The basic method of treatment and prevention in case of parasite infections in farm animals is to use anthelmintic preparations. However, the costs of such therapy are high and frequent applications of these preparations lead to the appearance of drug-resistant populations of parasites (Maingi et al., 1996; Coles, 1997).

A standard method for assessing the level of parasite burden in individual animals is a counting parasite eggs in faeces of these animals (faecal eggs count -. FEC). In literature there are different values of heritability for FEC. The heritability for FEC estimated by Charon et al. (2000) for the Polish Heath Sheep was 0.128.

Variation has been observed both among the animals of the same breed and between animals from different breeds in their resistance to parasite infections (Stear and Murray, 1994; Romjali et al., 1997). Special attention is paid in the studies on this variation to the major histocompatibility complex (MHC) (Beh and Maddox, 1996). The fundamental role in resistance to parasites is played by products of MHC genes class Il, as the task of these proteins is to induce the immune response in case of extracellular infection. MHC class II molecules are found only on the surface of special cells of the immune system, e.g. macrophages, which absorb foreign proteins or cells they encounter and while breaking them down to peptides, they present on their surface lymphocytes $\mathrm{T} \mathrm{CD}^{+}$through MHC antigens class II (Outteridge et al., 1996). The association of these peptides with resistance to the infection with some parasite species was confirmed by earlier studies on laboratory animals (Wassom et al., 1980; Geczy and Rothwell, 1981; Wakelin and Donachie, 1983).

The biggest polymorphism among the MHC genes is found in locus DRB, which codes the $\beta$ chain of the protein found in high concentrations on the surface of macrophages and lymphocytes B (Anderson and Rask, 1998). The $\alpha$ chain of this protein is coded by the dimorphic locus DRA. The DRB gene - thanks to its huge polymorphism - is thought to play a decisive role in the genetic control over the immune reaction of the organism to the appearance of a foreign antigen. The most frequently investigated fragment of the DRB gene covers exon 2 (it codes the binding site for a foreign protein - antigen) together with the microsatellite sequence in intron 2. The analysis of polymorphism of this fragment showed the presence of 19 alleles of the DRB1 gene in Scottish Blackface Sheep (Schwaiger et al., 1995). An association was found in these sheep between alleles of the DRB1 gene and resistance to natural infection with gastrointestinal parasites, among which the dominant species was Teladorsagia (Ostertagia) circumcincta.

The aim of the study was to analyse polymorphism of the DRB I gene (MHC class II) in the fragment containing exon 2 and the microsatellite in intron 2 on the basis of a flock of Polish Heath Sheep and further to investigate its relation to resistance to natural infection with gastrointestinal nematodes. 


\section{MATERIAL AND METHODS}

\section{Animals}

Two generations of Polish Heath Sheep (Romanov type) were examined over a period of four years (1995-1998). Ewes were 2-5 years old (246 individuals), while lambs (429 individuals) were 3-6 months old. The animals belonged to the flock of the Warsaw Agricultural University Experimental Farm. The Polish Heath Sheep is a primitive, prolific, unseasonal breed, short-tailed with black or white-spotted body ends and grey wool.

\section{Parasitological investigation}

Faecal egg counts (FEC) were estimated using the McMaster method (Bairden, 1991) four (in lambs) and six (in ewes) times during each grazing season. Each egg counted represented 50 worm eggs per 1 gram of faeces. Replicate counts were conducted for each sample. Parallel to FEC estimation, faecal cultures were run to determine the occurrence of specific nematode species. Infective third-stage larvae of nematode species were identified according to the method described in Anonymous (1986).

\section{Molecular analysis}

Blood of the examined animals was collected from the jugular vein to vacuum tubes containing an anticoagulant, EDTA. DNA was isolated using the method of phenol-chloroform extraction from whole blood. Polymorphism in locus DRB I was investigated in the parental generation - dams and rams ( 7 animals) as well as their progeny from the period of three years (1996-1998). The analysed fragment of the DRB I gene, coding the $\beta 1$ domain, a part of the peptide binding site, includes exon 2 and the microsatellite sequence $(\mathrm{gt})_{\mathrm{n}}(\mathrm{ga})_{\mathrm{m}}$ in intron 2 (Ammer et al., 1992; Ballingall et al., 1992; Schweiger et al., $1993 \mathrm{a}, \mathrm{b}$ ).

In order to amplify the DRB1 gene fragment using the PCR method, the following primers were used:

1: 5'-TCTCTGCAGCACATTTCCTGG-3' (6-FAM labelled) (Ammer et al., 1992)

2: 5'-CGTACCCAGAGTGAGTGAAGTATC-3' (Schwaiger et al., 1993a).

The PCR reaction was carried out in the Trio-Block thermocycler made by Biometra in the following conditions: $94^{\circ} \mathrm{C} / 3 \mathrm{~min} ; 55^{\circ} \mathrm{C} / 60 \mathrm{sec}$.; $72^{\circ} \mathrm{C} / 60 \mathrm{sec}$. 1 cycle; $94^{\circ} \mathrm{C} / 30 \mathrm{sec}$.; $55^{\circ} \mathrm{C} / 60 \mathrm{sec}$.; $72^{\circ} \mathrm{C} / 60$ sec. - thirty cycles; $94^{\circ} \mathrm{C} / 30 \mathrm{sec}$.; $55^{\circ} \mathrm{C} / 60 \mathrm{sec}$.; $72^{\circ} \mathrm{C} / 5 \mathrm{~min}-1$ cycle (Gruszczyńska et al., 2000). 
The length of the obtained PCR product established using the automatic capillary sequencer ABI Prism 310 (Perkin Elmer) using POP.4 polymere and GeneScan ${ }^{\circledR} 2.1$. software was used to identify alleles in locus DRB1.

\section{Statistical analysis}

The analysis of the association between the alleles identified in locus DRB1 and the number of gastrointestinal nematode eggs in sheep faeces concerned these animals that were subjected at least three times to parasitological examinations. In order to obtain the normal distribution of the FEC value, each counting of the nematode eggs in sheep faeces was transformed onto the logarithmic scale, according to the following formula: $\mathrm{LFEC}=\log (\mathrm{FEC}+1)$ (Bishop et al., 1996; Romjali et al., 1997). The analysis of variance in case of LFEC in genotypic groups used the mean number of eggs in faeces calculated after transformation for each individual. In the first stage of analysis, the effects of the type of birth (the litter size - single, twins or triplets), sex and year of birth were examined for FEC using the GLM procedure of the SAS package (1990). Statistically significant effects were included in the statistical analysis.

The significance of the genotypic group effect was tested using the F test. In these calculations a total number of $250 \mathrm{FEC}$ observations were used along with 38 genotypes in locus DRB1.

In order to determine the effect of DRB1 alleles on the nematode faecal egg count in the Polish Heath Sheep (an indicator of resistance/susceptibility to nematode infections), the logistic regression (B) was estimated using the maximum likelihood method according to the following model (Stanisz, 2000):

$$
\mathrm{P}\left(\mathrm{Y}=1 \mid \mathrm{x}_{1}, \mathrm{x}_{2}, \ldots \mathrm{x}_{\mathrm{k}}\right)=\frac{\mathrm{e}^{\left(a_{0}+\sum_{i=1}^{k} a_{i} x_{i}\right)}}{1+\mathrm{e}^{\left(a_{0}+\sum_{i=1}^{k} a_{x_{i}}\right)}}
$$

where:

$\mathbf{Y}$ is the dependent variable (FEC)

$\mathbf{a}_{\mathbf{i}} \mathbf{i}=\mathbf{0}, \ldots, \mathbf{k}$ are regression coefficients

$\mathbf{x}_{1}, \mathbf{x}_{2}, \ldots, \mathbf{x}_{\mathbf{k}}$ are independent variables (DRB1 alleles).

Moreover, the unitary odds ratio (OR) was also calculated according to the formula:

$$
\operatorname{InS}(\mathrm{A})=\operatorname{In} \frac{p(\mathrm{Y}=1)}{1-p(\mathrm{Y}=1)}
$$


where:

$\mathbf{p}(\mathbf{Y}=\mathbf{1})$ is the probability that animals having a given allele in their genotype are resistant to nematode infections.

The analysis was conducted for alleles with the frequency exceeding $2 \%$. The calculations were conducted using the SPSS 10.1 PL for Windows software.

Moreover, the variability of the LFEC trait was investigated in paternal allelic groups. The analysis of variance was conducted to verify the hypothesis of the equality of means in paternal allelic groups, with the use of the following model:

$$
Y_{i j k l m}=\mu+s_{i}+g_{i j}+R_{k}+L_{1}+e_{i j k k m}
$$

where:

$\mu$ is the overall mean

$\mathbf{s}_{\mathrm{i}}$ is the effect of $\mathrm{i}$-th sire

$\mathbf{g}_{\mathbf{i j}}$ is the effect of $\mathbf{j}$-th allelic group within the paternal group of half-sibs; $\mathbf{j}=1,2$, while the criterion for the observation to belong to a given allelic group was the identification in the offspring of one out of the two paternal alleles (allele 1 or 2)

$\mathbf{R}_{\mathrm{k}}$ is the effect of sex (male, female)

$L_{1}$ is the effect of year of birth $\mathbf{e}_{\mathrm{jkin}}$ is a random crror.

The significance of the allelic group effects was tested using the $\mathrm{F}$ test and t-student test. The size of paternal half-sibs groups ranged from 34 offspring of ram No 585 to 46 offspring of ram No 528 , while mean paternal sibships size was 40.14 . However, only observations coming from animals in which their belonging to a given allelic group could be determined on the basis of investigations of allele segregation were included in the analysis. In the study only those groups of half-sibs were taken into consideration in which both allclic subgroups had at least three observations.

The calculations were made using the GLM procedure (General Linear Model) of the SAS package (1990).

\section{RESULTS AND DISCUSSION}

The intensity of infection of the investigated flock with gastrointestinal nematodes was characterised by considerable variability, ranging in case of dams from 0 to 24000 eggs and in the group of lambs from 0 to over 27000 eggs in 1 gram of faeces. It needs to be mentioned, however, that these maximum values of egg counts in the faeces of infected sheep were observed extremely rarely. Usually the intensity in case of dams did not exceed 7000 eggs and in case of lambs 5000 eggs in 1 gram of faeces. Detailed results on prevalence of gastrointestinal nematode infection in the investigated flock were presented by Charon et al. (2000). 
The number of gastrointestinal nematode eggs in animal faeces is assumed by researchers dealing with this problem as a marker of resistance to the infection with these parasites (Paterson et al., 1998; Baker, 1999). The high variability in the number of eggs in the faeces of investigated animals indicates individual differences in resistance/susceptibility to gastrointestinal nematode infections within the Polish Heath Sheep breed. It is also confirmed by observations by other authors (Bouix et al., 1998) who found that on individual dates of testing the intensity of infection in case of long-wool sheep rarely exceeded $7000 \mathrm{eggs} / 1$ gram of faeces and as a rule ranged from 0 to $4600 \mathrm{eggs} / 1 \mathrm{gram}$ of faeces.

The examinations of faecal cultures, conducted simultaneously with the determination of nematode egg counts, showed that in the years 1995-1997 the dominant species in gastrointestinal parasite infections of the Polish Heath Sheep were nematodes Haemonchus contortus and Trichostrongylus colubriformis. In the last year of the study, i.e. in 1998, a decisive change took place as over $30 \%$ of sheep were infected with Teladorsagia (Ostertagia) circumcincta, in comparison to $5-8 \%$ of sheep infected with that nematode in the previous years. Detailed results are given by Charon et al. (2000).

The analysis of polymorphism of the DRB1 gene fragment, including exon 2 and the microsatellite within intron 2, indicated the occurrence of 20 alleles with the lengths from $454 \mathrm{bp}$ to $576 \mathrm{bp}$ in the investigated flock. These results confirm the polymorphism in sheep of this MHC region class II mentioned by other researchers (Schwaiger et al., 1993b). McCririe et al. (1997), on the basis of differences in the lengths of the microsatellite sequence within the DRB1 gene, distinguished eight alleles in the group of twenty one lambs of the Scottish Blackface Sheep. Authors investigating a bigger group of sheep coming from that breed (Buitkamp and Epplen, 1996) found the occurrence of as many as 17 alleles of the microsatellite sequence in intron 2 of that gene, while Schwaiger et al. (1995) showed the occurrence of 19 alleles. On the other hand, Paterson ct al. (1998), examining a large unmanaged population of Soay sheep (1,209 animals studied) on St. Kilda archipelago, found 5 alleles of the DRB1 gene, only.

The frequency of individual alleles, identified on the basis of the length of the amplified fragment of the DRBl gene, is presented in Table 1. In the flock of dams, allele 488 bp occurred with the highest frequency, whereas in case of lambs the highest frequency was observed for allele $506 \mathrm{bp}$. Both these alleles showed the highest frequency in the investigated flock. The frequency of occurrence for individual alleles was similar in lambs and in the flock of dams. The only distinct difference was observed in case of allele $530 \mathrm{bp}$, which was present in only $0.4 \%$ dams and in over $3 \%$ of lambs.

The conducted analysis of the association between the number of nematode eggs in sheep faeces and genotype in locus DRB 1 showed a statistically significant relationship $(\mathrm{F}=2.14 ; \mathrm{P} \leq 0.01)$. 
TABLE 1

Frequency of allcles in locus DRB i in the investigated flock of Polish Heath Shecp

\begin{tabular}{|c|c|c|c|c|c|c|c|}
\hline \multirow{2}{*}{$\begin{array}{l}\text { Allele } \\
\text { (bp) }\end{array}$} & \multicolumn{3}{|c|}{ Allele frequency } & \multirow{2}{*}{$\begin{array}{l}\text { Allele } \\
\text { (bp) }\end{array}$} & \multicolumn{3}{|c|}{ Allcle frequency } \\
\hline & ewes & lambs & total & & ewes & lambs & lotal \\
\hline 454 & 0.018 & 0.016 & 0.019 & 516 & 0.107 & 0.087 & 0.082 \\
\hline 468 & 0.053 & 0.048 & 0.046 & 520 & 0.004 & 0.001 & 0.001 \\
\hline 474 & 0.011 & 0.013 & 0.010 & 526 & 0.028 & 0.067 & 0.074 \\
\hline 478 & 0.004 & 0.005 & 0.006 & 530 & 0.004 & 0.033 & 0.028 \\
\hline 482 & 0.096 & 0.069 & 0.072 & 536 & 0.068 & 0.034 & 0.040 \\
\hline 488 & 0.200 & 0.165 & 0.163 & 540 & 0.007 & 0.004 & 0.007 \\
\hline 494 & 0.011 & 0.005 & 0.010 & 550 & 0.025 & 0.009 & 0.018 \\
\hline 500 & 0.104 & 0.088 & 0.090 & 560 & 0.064 & 0.053 & 0.050 \\
\hline 506 & 0.096 & 0.211 & 0.181 & 568 & 0.061 & 0.065 & 0.069 \\
\hline 510 & 0.025 & 0.019 & 0.027 & 576 & 0.014 & 0.008 & 0.007 \\
\hline
\end{tabular}

The effect of individual alleles on the resistance/susceptibility of sheep to nematode infections was assessed on the basis of values of the estimated coefficient of logistic regression and the odds ratio (Table 2). Alleles with the frequency below $2 \%$ in the investigated flock were neglected in these calculations. The value of the coefficient of logistic regression indicates that the occurrence of alleles $468 \mathrm{bp}, 482$ bp or $530 \mathrm{bp}$ in the genotype of the investigated sheep had a significant effect on the resistance to nematode infections. The average nematode egg count in case of animals possessing this allele was below the average FEC value for the flock.

TABLE 2

The coefficient of logistic regression (B), the level of probability $(\mathrm{P})$ and the odds ratio $(\mathrm{OR})$ for alleles from locus DRB!

\begin{tabular}{cccc}
\hline Allele (bp) & B & $\mathrm{P}$ & OR \\
\hline 468 & $0.727^{*}$ & 0.044 & 2.069 \\
482 & $1.165^{*}$ & 0.001 & 3.206 \\
488 & 0.212 & 0.281 & 0.809 \\
500 & -0.066 & 0.797 & 0.936 \\
506 & 0.032 & 0.857 & 0.968 \\
510 & 0.707 & 0.201 & 2.027 \\
516 & $-0.684^{*}$ & 0.011 & 0.504 \\
526 & 0.126 & 0.664 & 1.056 \\
530 & $1.007^{*}$ & 0.038 & 2.738 \\
536 & -0.160 & 0.690 & 0.852 \\
560 & 0.259 & 0.423 & 1.122 \\
568 & $-0.976^{*}$ & 0.003 & 0.377 \\
\hline
\end{tabular}

* - coefficient statistically significant (at P shown in Table 2) 
The odds ratio defines the probability of the nematode faecal egg count lower that the average FEC value for the flock in case of a sheep who is the carrier of the DRB1 allele. The obtained results (Table 2) indicate that the probability of an increased nematode egg count (FEC > the flock average) in sheep with the $468 \mathrm{bp}$ allele is two times lower than in sheep not possessing this allele, whereas in sheep with alleles $482 \mathrm{bp}$ or $530 \mathrm{bp}$ it is three times lower. However, the frequencies of these alleles in the sheep flock were low, within the 3-7\% range. A confirmation of the dependence between the given DRB1 alleles and the FEC value are positive coefficients of regression.

The occurrence of alleles 516 bp and 568 bp had a significant, but negative effect on the resistance of the investigated sheep to nematode infections. However, the probability that a sheep having one of these alleles in the genotype will be resistant to nematode infections, expressed in terms of the odds ratio, is 50 and below $40 \%$, respectively.

Alleles 488 bp and 506 bp with the highest frequencies in the flock (16.3 and $18.1 \%$, respectively), in spite of the more frequent occurrence in the genotype of sheep from group 1 (their average FEC $<$ the flock FEC average), did not have a significant effect on the resistance of sheep to nematode infections.

$\begin{array}{lllllllllllll}\text { LFEC }^{\text {a }} & 468 & 482 & 488 & 500 & 506 & 510 & 516 & 526 & 530 & 536 & 560 & 568\end{array}$

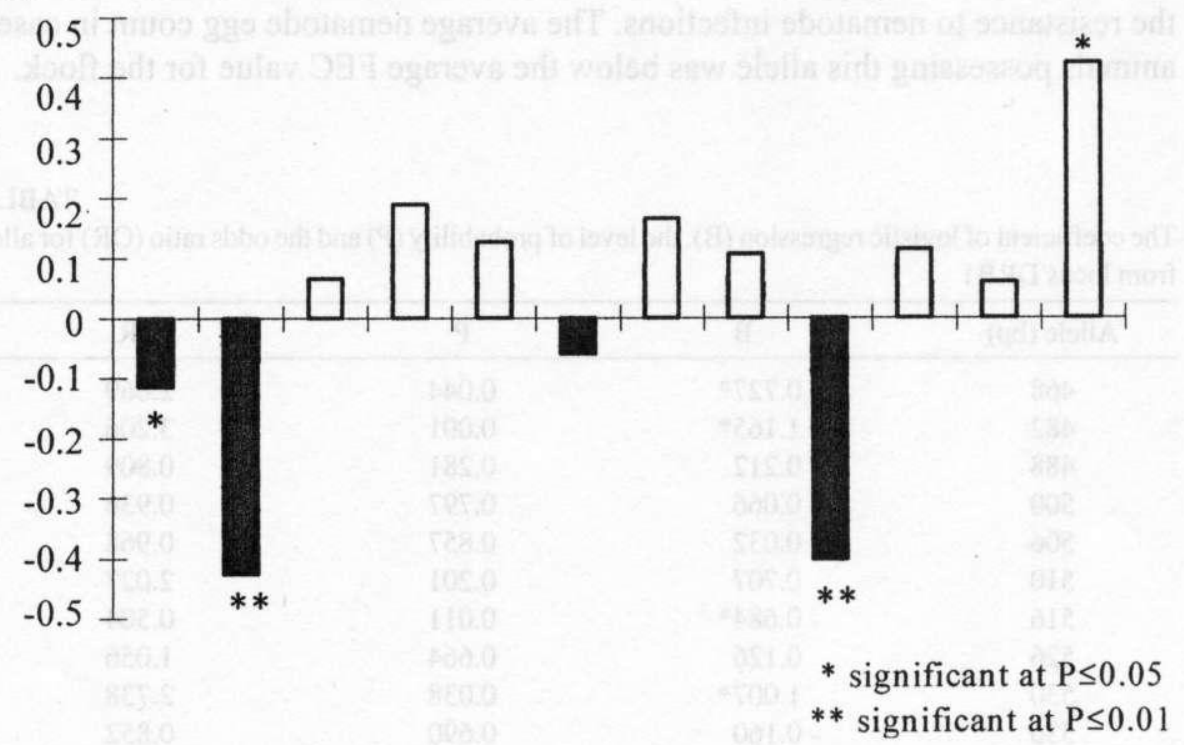

a deviation in FEC in logarithmic scale (LFEC) from the mean LFEC accepted as 0

Figure 1. The effect of DRB1 alleles on FEC 
The effect of individual DRB1 alleles on resistance/susceptibility to nematode infection was evaluated. The Figure 1 presents a deviation in the logarithmic nematode egg counts from the mean LFEC (2.569, which is equal to 369.94 eggs per gram) obtained for studied animals and accepted as 0 in diagram. The result of multiple comparisons (allele present in the genotype vs allele absent in the genotype) showed that among 12 alleles (with a frequency of more than $2 \%$ ) included in this analysis, the presence of alleles: $468 \mathrm{bp}, 482 \mathrm{bp}$ and $530 \mathrm{bp}$ was significantly connected with lower FEC, while 568 bp allele with higher FEC than the overall mean of nematode egg counts (Figure 1).

Also in other sheep breeds a relation was found between genotype in locus $\mathrm{DRBI}$ and resistance to natural infection with gastrointestinal parasites. Schwaiger et al. (1995) obtained similar results for Scottish Blackface Sheep, in which the dominant species among gastrointestinal nematodes was $T$. circumcincta. The results obtained by these researchers suggested that the replacement of one of the most frequent alleles in that flock, denoted with the symbol I, with allele G2 "resistance" to nematodes, would lead to the number of eggs in the faeces of 6 -month old lambs being to less than $2 \%$ of the original value.

Similar methods of MHC polymorphism analysis were used in case of Merino sheep by Outteridge et al. (1996). Examinations of family groups conducted by them showed that two out of eight alleles of the DRB1 gene occurred with high frequency in the genotypes of lambs characterised by low FEC values. However, the authors made it clear that the relation of these alleles with resistance to gastrointestinal nematodes should be confirmed by further studies.

Paterson et al. (1998), investigating association of microsatellite polymorhpism in DRB I gene with parasite resistance in lambs and yearlings of Soay sheep, showed that the DRB 1257 allele was significantly associated with decrease parasite resistance in lambs, while the DRB 263 allele was associated with increased parasite resistance in yearlings. The remaining alleles had no effect on sheep resistance/ susceptibility to parasite infections.

Table 3 presents the number of observations, the mean transformed number of gastrointestinal nematode eggs in the faeces of investigated sheep and LFEC standard deviation in individual allelic groups of paternal half-sibs.

The analysis of variance for the mean values of LFEC in paternal allelic groups showed significant differences $(\mathrm{F}=1.79 ; \mathrm{P} \leq 0.05)$ in the level of infection between the allelic groups in terms of sires. A relation between DRBl alleles segregation and the variability of gastrointestinal nematode egg counts was significant in halfsibs progeny of three rams among seven investigated (Table 3 ).

The obtained results indicate a possibility to use alleles of the DRB 1 gene as selection markers in the improvement of the resistance of sheep to gastrointestinal parasite infection. 
TABLE 3 Averages and the standard deviation (SD) of nematode egg counts (in logarithmic scale) in sheep faeces for allclic paternal groups

\begin{tabular}{|c|c|c|c|c|c|c|}
\hline \multirow[t]{2}{*}{ Ram } & \multirow{2}{*}{$\begin{array}{c}\text { Genotype in } \\
\text { locus DRBl (bp) }\end{array}$} & \multirow{2}{*}{$\begin{array}{l}\text { Allelic } \\
\text { group }\end{array}$} & \multirow{2}{*}{$\begin{array}{l}\text { Allele } \\
(b p)\end{array}$} & \multirow{2}{*}{$\begin{array}{c}\text { Number of } \\
\text { observations }\end{array}$} & \multicolumn{2}{|c|}{ LFEC } \\
\hline & & & & & mean & SD \\
\hline \multirow[t]{2}{*}{$414 * *$} & $530 / 568$ & 1 & 530 & 15 & 2.428 & 1.355 \\
\hline & & 2 & 568 & 16 & 3.940 & 0.575 \\
\hline \multirow[t]{2}{*}{528} & $506 / 560$ & 1 & 506 & 16 & 3.308 & 0.620 \\
\hline & & 2 & 560 & 6 & 3.480 & 0.974 \\
\hline \multirow[t]{2}{*}{585} & $500 / 526$ & 1 & 500 & 8 & 3.432 & 0.925 \\
\hline & & 2 & 526 & 8 & 3.592 & 1.022 \\
\hline \multirow[t]{2}{*}{1050} & $488 / 506$ & 1 & 488 & 14 & 3.141 & 1.022 \\
\hline & & 2 & 506 & 5 & 3.486 & 1.012 \\
\hline \multirow[t]{2}{*}{2256} & $468 / 560$ & 1 & 468 & 9 & 2.678 & 1.260 \\
\hline & & 2 & 560 & 3 & 3.082 & 0.593 \\
\hline \multirow[t]{2}{*}{$2852^{* * *}$} & $506 / 516$ & 1 & 506 & 5 & 3.576 & 0.155 \\
\hline & & 2 & 516 & 7 & 4.403 & 0.385 \\
\hline \multirow[t]{2}{*}{$293 !^{*}$} & $506 / 526$ & 1 & 506 & 10 & 2.877 & 1.174 \\
\hline & & 2 & 526 & 11 & 3.450 & 0.952 \\
\hline
\end{tabular}

group - occurrence in the genotype of one out of two paternat alleles: allele 1 (group 1) or allele 2 (group 2)

b the sum of observations is the number of offspring sired by a given individual

* differences significant at $\mathrm{P} \leq 0.01$

** differences significant at $\mathrm{P} \leq 0.001$

\section{CONCLUSIONS}

The investigated fragment of the DRB 1 gene, including exon 2 and the adjoining microsatellite sequence in intron 2 , was highly polymorphic, a total number of 20 alleles ( $454 \mathrm{bp}$ to $576 \mathrm{bp}$ ), were identified in the examined flock of sheep.

The analysis of the association between polymorphism in locus DRBI and the faecal nematode egg counts (FEC) showed that some alleles of the DRB1 gene may be connected with the resistance/suscpetibility of the Polish Heath Sheep to infections by gastrointestinal nematodes. Alleles $468 \mathrm{bp}, 482 \mathrm{bp}$ and $530 \mathrm{bp}$ showed significant $(\mathrm{P} \leq 0.05, \mathrm{P} \leq 0.01$ and $\mathrm{P} \leq 0.04$, respectively) association with resistance to parasitic infections. Conversely, the DRB -516 bp and 568 bp alleles acted significantly $(\mathrm{P} \leq 0.01)$ to decrease nematode egg counts in sheep carrying these alleles.

The segregation of rams' DRB1 allcles had significant effect $(\mathrm{P} \leq 0.05)$ on resistance of paternal halb-sibs to gastrointestinal parasites. 


\section{REFERENCES}

Ammer H., Schwaiger F-W., Kammer-Baver C., 1992. Exonic polymorphism vs. intronic simple repeat hypervariability in MHC DRB genes. Immunogenetics 35, 332-340

Anderson L., Rask L., 1998. Characterisation of the MHC class If region in cattle: The number of DQ genes varies between haplotypes. Immunogenetics 27, 1 10-120

Anonymous, 1986. Manual of Veterinary Parasitological Techniques. Ministry of Agricuture, and Food, Her Majesty's Stationary Office, London

Bairden K.,1991. Ruminant parasitic gastritis; some observations on epidemiology and control. Ph.D. Thesis, University of Glasgow

Baker R.L., 1999. Genetics of resistance to endoparasites and ectoparasites. Int. J. Parasitol. 29, 7375

Ballingall K.T., Wright H., Redmond J., Dutia B.M., Hopkins J., Lang J., Deverson E.V., Howard J.C., Puri N., Haig D., 1992. Expression and characterisation of ovine major histocompalibility complex class II-(OLA-DR) genes. Anim. Genct. 23, 347-359

Beh K. J., Maddox J. F.,1996. Prospects for development of genetic markers for resistance to gastrointestinal parasite infection in sheep. Int. J. Parasitol. 26, 879-897

Bishop S.C., Bairden K., McKellar Q.A., Park M., Stear M. J., 1996. Genetic parameters for faecal egg count following mixed, natural, predominantly Ostertagia circumcincta infection and relationships with live weight in young lambs. Anim. Sci. 63, $423-428$

Bouix J., Krupiński J., Rzepecki R., Nowosad B., Skrzyżala I., Roborzyński M., FudalcwiczNiemczyk W., Skalska M., Malczewski A., Gruner L., 1998. Genetic resistance to gastrointestinal nematode parasites in Polish long-wool sheep. Int. J. Parasitol 28, 1797-1804

Buitkamp J., Epplen J.T., 1996. Major histocompatibility and T - cells receptor genes in Artiodactyls: characterization, polymorphism and genetic resistance to a helmintic infection. J. Anim. Breed. Genet. 113, 287-291

Charon K.M., Moskwa B., Nowak Z., Szydłowski M., 2000. Genelic parameters for faecal egg count following natural nematode infections and correlation with productive traits in Polish Heath sheep. J. Anim. Feed Sci. 9, 46!-470

Coles G.C., 1997. Nematode control practices and anthelmintic resistance on British sheep farms. Vet. Rec. 141(4), $91-93$

Geczy A. F., Rothwell T. L. W., 1981. Genes within the major histocompatibility complex of guinea pig influence susceptibility to Trichostrongylus colubriformis infection. Parasitology 82,281 286

Gruszczyńska J., Charon K.M., Kitlińska J., Szydłowski M., 2000. The influence of OLA-DRB 1 (MHC class II) gene polymorphism on lamb body weight and weight gain in Polish Heath Sheep. J. App!. Genet. 41, 101-112

Maingi N., Bjorn H., Thamsborg S.M., Bogh H.O., Nansen P., 1996, Anthelmintic resistance in nematode parasites of sheep in Denmark. Small Ruminant Res. 23, 171-18!

McCririe L., Bairden K., Britton C., Buitkamp J., McKeand J. B., Stear M. J., 1997. Heterogenity in the recognition of Ostertagia circumcincta antigens by scrum antibody from mature, infected shecp. Parasite Immunol. 19, 235-242

Outteridge P.M., Anderson L., Douch P.G.C., Green R.S., Gwakisa P.S., Hohenhaus M.A., Mikko S., 1996. The PCR typing of MHC - DRB genes in the sheep using primers for an intronic microsatellite: application to nematode parasite resistance. Immun.Cell Biol. 74, 330-336

Paterson S., Wilson K., Pemberton J.M., 1998. Major histocompatibility compex variation associated with juvenile survival and parasite resistance in a large unmanaged ungulate population (Ovis aries L.). P.N.A.S. 95, 3714-3719 
Romjali E., Pandey V.S., Gatenby R.M., Doloksaribu M., Sakul H., Wilson A., Verchulst A., 1997. Genetic resistance of different genotypes of sheep to natural infections with gastro-intestinal nematodes. Anim. Sci. 64, 97-104

SAS, 1990. SAS(B) Procedures Guide. Version 6. $4^{\text {th }}$ Edition. SAS Institute Inc. Cary, NC

Schwaiger F.-W., Buitkamp J., Weyers E., Epplen J. T., 1993a. Typing of artiodactyl MHC-DRB gencs with the help of intronic simple repeated DNA sequences. Mol. Ecol. 2, 55-59

Schwaiger F.W., Gostomski D., Stear M.J., Duncan J.L., McKellar Q.A., Epplen J. T Buitkamp J., 1995. An ovine major histocompatibility complex DRB1 allele is associated with low faecal egg counts following natural, predominantly Ostertagia circumcincta infection. Int. J. Parasitol. 25, $815-822$

Schwaiger F-W., Wayers E., Epplen C., Brun J., Ruff G., Crawford A., Epplen J.T., 1993b. The paradox of $\mathrm{MHC}-\mathrm{DRB}$ exon/intron evolution: $\alpha$-helix and $\beta$-shect encoding regions diverge while hypervariable intronic simple repeats coevolve with $\beta$-sheet codons. J. Mol. Evol. 37, 260272

Stanisz. A., 2000. The Course of Statistics Using Statistica PL Program for Human Medicine (in Polish). Vol. II. StatSoft Poland, Kraków

Stear M.J., Murray M., 1994. Genetic resistance to parasitic discase: particularly of resistance in ruminants to gastrointestinal nematodes. Vet. Parasitol. 54, 161-176

Wakelin D., Donachic A.M., 1983. Genetic control of immunity to Trichinella spiralis: Intluence of H-2 linked genes on immunity to the intestinal phase of infection. Immunology 48, 343-350

Wassom D.L., David C.S., Gleich G.J., 1980. MHC-linked genetic control of the immune response to parasites: Trichinella spiralis in the mouse. In: E. Skamene, P.A.L. Kongshavn, M. Landy (Editors). Genetic Control of Natural Resistance to Infection and Malignancy. Academic Press, New York, pp. 75-78

\section{STRESZCZENIE}

Polimorfizm mikrosatelitarny w genie DRB1 (MHC klasa II) i jego związek z liczbą jaj nicieni w kale owiec rasy wrzosówka

W stadzie owiec rasy wrzosówka w latach 1995-1998 prowadzono badania parazytologiczne i badania polimorfizmu w locus DRBl, należącym do MHC klasy II. Intensywność zarażenia matek wahała się od 0 do 24000 jaj, a jagniąt do 270000 jaj nicieni w gramie kału. W latach 1995-1997 gatunkami nicieni dominującymi w infekcji były H.contortus i T. colubriformis, natomiast w 1998 roku głównym gatunkiem fauny parazytologicznej przewodu pokarmowego był $T$. circumcincta.

Analiza DNA badanych owiec wykazała obecność 20 alleli w locus DRB1, określanych na podstawic długości amplifikowanego za pomocą PCR fragmentu tego genu (ekson 2 + mikrosatelita w intronie 2).

Przeprowadzona analiza wariancji cechy FEC w grupach genotypowych wykazała statystycznie istotny $(P \leq 0,01)$ wpływ genotypu w locus DRB 1 na liczbę jaj nicieni w kale owiec. Obecność określonego allelu w genotypie badanych zwierząt miała istotny wpływ na odponość na pasożyty. Również istotna $(\mathrm{P} \leq 0,05)$ była zależność między wartością FEC w grupach allelicznych półrodzcństwa ojcowskiego a segregacją alleli ojcowskich. 